Review

\title{
Candida Infection Associated with Salivary Gland-A Narrative Review
}

\author{
Soo-Min Ok ${ }^{1,2,3} \mathbb{D}^{\mathbb{D}}$, Donald Ho ${ }^{3}$, Tyler Lynd ${ }^{3}$, Yong-Woo Ahn ${ }^{1,2}$, Hye-Min Ju ${ }^{1,2} \mathbb{D}$, Sung-Hee Jeong ${ }^{1,2} \mathbb{D}$ and \\ Kyounga Cheon ${ }^{3, *(\mathbb{D})}$ \\ 1 Department of Oral Medicine, Dental and Life Science Institute, Pusan National University, \\ Yangsan 50612, Korea; oksoomin@pusan.ac.kr (S.-m.O.); ahnyongw@pusan.ac.kr (Y.-W.A.); \\ hyungtaejoa@naver.com (H.-M.J.); drcookie@pusan.ac.kr (S.-H.J.) \\ 2 Dental Research Institute, Pusan National University Dental Hospital, Yangsan 50612, Korea \\ 3 Department of Pediatric Dentistry, University of Alabama at Birmingham, Birmingham, AL 35294, USA; \\ donaldho@uab.edu (D.H.); tlynd@uab.edu (T.L.) \\ * Correspondence: kcheon@uab.edu
}

check for updates

Citation: Ok, S.-M.; Ho, D.; Lynd, T.; Ahn, Y.-W.; Ju, H.-M.; Jeong, S.-H.; Cheon, K. Candida Infection Associated with Salivary Gland-A Narrative Review. J. Clin. Med. 2021, 10, 97. https://doi.org/10.3390/ jcm10010097

Received: 29 November 2020 Accepted: 26 December 2020 Published: 30 December 2020

Publisher's Note: MDPI stays neutral with regard to jurisdictional clai$\mathrm{ms}$ in published maps and institutional affiliations.

Copyright: (C) 2020 by the authors. Licensee MDPI, Basel, Switzerland. This article is an open access article distributed under the terms and conditions of the Creative Commons Attribution (CC BY) license (https:// creativecommons.org/licenses/by/ $4.0 /)$.

\begin{abstract}
Candida species are common global opportunistic pathogens that could repeatedly and chronically cause oral mucosa infection and create an inflammatory environment, leading to organ dysfunction. Oral Candida infections may cause temporary or permanent damage to salivary glands, resulting in the destruction of acinar cells and the formation of scar tissue. Restricted function of the salivary glands leads to discomfort and diseases of the oral mucosa, such as dry mouth and associated infection. This narrative review attempts to summarize the anatomy and function of salivary glands, the associations between Candida and saliva, the effects of Candida infection on salivary glands, and the treatment strategies. Overall, clinicians should proactively manage Candida infections by educating patients on oral hygiene management for vulnerable populations, conducting frequent checks for a timely diagnosis, and providing an effective treatment plan.
\end{abstract}

Keywords: oral candidiasis; salivary gland; saliva; treatment

\section{Introduction}

Salivary glands, an essential component to maintaining oral health, are susceptible to a variety of pathologies, including candidiasis. The salivary glands are commonly classified as either major or minor salivary glands based on their sizes, distributions, and functional characteristics [1]. The major salivary glands consist of the parotid, submandibular, and sublingual glands [2], which produce and secrete saliva, moisturize intraoral mucosa and teeth, maintain oral hygiene, and facilitate taste, swallowing, speech, and mastication [3]. The minor salivary glands are distributed throughout oral mucosa surfaces, producing mucous saliva with organic substances, even at night, and protect oral mucosa from injury [4-6]. Notably, salivary glands produce high concentrations of the secretory immunoglobulin (Ig) A, which prevents other Igs from being broken down by proteolytic enzymes from microbes $[7,8]$. These critical functions of saliva are repressed when the salivary glands are damaged by Candida infections.

Candida is a genus of yeast and major human fungal pathogens [9]. Candida species are opportunistic pathogens that could repeatedly and chronically cause oral mucosa infections [10,11]. The most prevalent species found in oral Candida infection is Candida albicans, due to its cell adherence properties and great pathogenic potential [12]. C. albicans is isolated from more than $80 \%$ of oral Candida lesions [13]. Other clinically relevant species include Candida glabrata, Candida tropicalis, Candida parapsilosis, Candida kefyr, Candida dubliniensis, Candida lusitaniae, Candida krusei, and Candida guilliermondii [14]. It has been reported that $30-45 \%$ of healthy adults carry oral Candida organisms, and $25-80 \%$ of adults develop oral candidiasis under the condition of using antibiotics, steroids, or 
immunosuppressants; impaired salivary gland function; improperly fitted dentures; poor oral hygiene; and a high carbohydrate diet. Additionally, 49-54\% of healthy infants carry oral Candida organisms, and 5-7\% of infants develop oral candidiasis [15,16]. In general, the most commonly affected populations are middle-aged to elderly people. Prevalence rates as high as $70 \%$ have been reported in nursing-home residents [17]. Denture-associated oral candidiasis is frequent and occurs globally. Additionally, females are affected slightly more frequently than males [17]. Oral candidiasis also occurs in immunocompromised patients, with an estimated prevalence of $9-31 \%$ of acquired immunodeficiency syndrome (AIDS) patients and $20 \%$ of cancer patients [18].

Host inflammatory reaction to Candida infection may negatively affect salivary gland tissue and function. During Candida infection, epithelial leukocyte penetration and subepithelial inflammation are observed in histological examinations [19]. The inflammatory mediators, such as chemokines and cytokines (TNF- $\alpha$, IL-6, and IL1 $\beta$ ), are secreted from oral epithelial cells and phagocytic cells, including neutrophils, macrophages, and dendritic cells [19]. The inflammatory reaction could damage salivary glands in the form of sialectasis, ductal ectasia, and progressive acinar destruction. The sublingual and minor salivary glands are located in the superficial layer of the oral mucosa and may be more vulnerable to inflammatory-mediated damage.

Based on clinical observation and pathological evidence from the literature, this review article discusses the anatomy and function of the salivary gland, the association between Candida and saliva, the effects of oral Candida infection on salivary glands, and treatment strategies to combat Candida infection.

\section{Anatomy and Function of the Salivary Glands}

To understand the implications of Candida infection and how it affects salivary glands, the anatomy and function of normal salivary gland are described. As shown in Figure 1, there are three major salivary glands: parotid, submandibular, and sublingual glands in the oral cavity. The paired parotid glands are the largest of the major salivary gland; they are encapsulated and located lateral to the ramus of the mandible [20]. The parotid gland consists mainly of serous acini, secreting $\alpha$-amylase-rich saliva. Saliva $\alpha$-amylase is known to play a secondary role in preventing bacterial attachment to the oral surface and removing bacteria from the oral cavity [21]. The paired submandibular glands are the second largest salivary gland, located in the submandibular triangle, consisting of anterior and posterior digastric muscles, and lower border of the mandible, making up the posterior part of the floor of the mouth, above the mylohyoid muscle. The submandibular glands are composed of mixed acini populations with mucous and serous function [20]. The sublingual glands are the smallest major salivary gland and are located right under the mucous membrane at the floor of the mouth [22]. Unlike the parotid and submandibular glands, the sublingual glands are not encapsulated and spread throughout the sublingual space. The sublingual space is just below the floor of mouth and above the mylohyoid muscles. The sublingual glands secrete mucous saliva, a viscous solution rich in mucins. While the parotid and submandibular glands have long branched ducts containing all the ductal segments (excretory, intercalated, and striated), the sublingual glands lack striated ducts. The three main salivary glands account for more than $90 \%$ of secreted saliva by volume. 


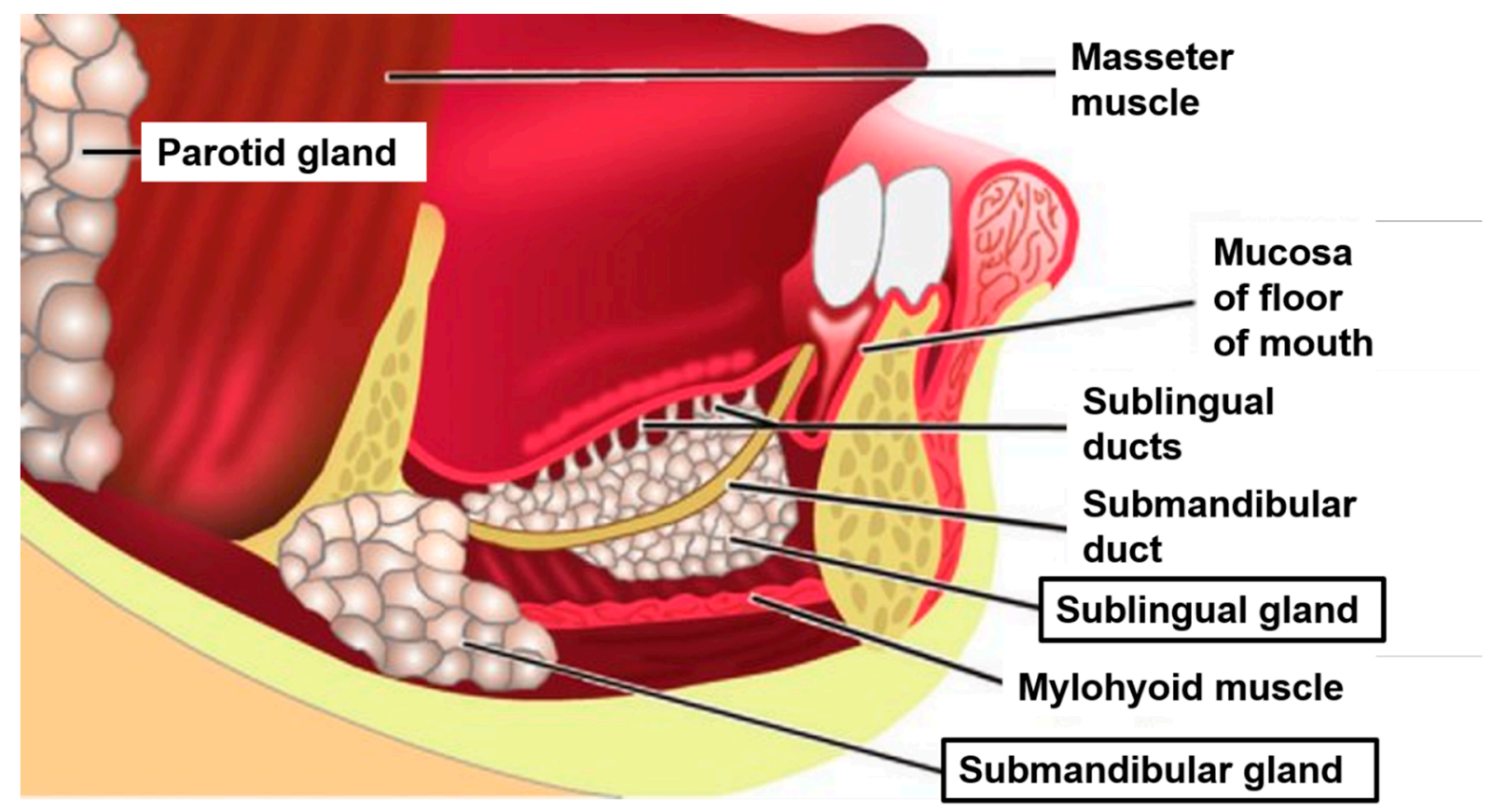

Figure 1. Drawing shows the location of the major salivary glands and its ducts. Note: Sublingual gland is located below the oral epithelium of the floor of the mouth. Adapted with permission of Radiological Society of North America, from "Imaging the Floor of the Mouth and the Sublingual Space", 31, 5, 2011 [23]; permission conveyed through Copyright Clearance Center, Inc.

Minor salivary glands are located in the submucosa, where they are surrounded by connective tissue, or embedded between muscle fibers (Figure 2). Between 600 and 1000 minor salivary glands are scattered throughout the oral mucosa except for the gingiva, the anterior dorsal aspect of the tongue, the midline and anterior part of the hard palate. Minor salivary glands consist of small secretory cell clusters with short excretory ducts that convey saliva products to the mucosal surface [4]. Minor salivary glands have a diameter of 1-5 $\mathrm{mm}$ and no actual capsule like the sublingual gland. Most of the minor salivary glands secrete mucus saliva; however, Von Ebner glands secrete serous or mixed saliva. The Von Ebner glands are adjacent to the foliate and circumvallate papillae in the dorsum and posterior tongue [4]. Although minor salivary glands produce about $10 \%$ of the total saliva volume [24], the minor salivary glands are widely distributed throughout the oral submucosa and secrete an abundance of salivary mucins, which acts as a lubricant. Mucin is important component of saliva, to avoid the subjective sensation of oral dryness [6]. By secretion of salivary mucins from the minor salivary glands, the formation of a lubricating film on the oral surfaces contributes to mucosal wetting and protection [5]. Meanwhile, researchers demonstrated that the flow rate of the minor salivary glands is a critical factor for dry-mouth assessment $[25,26]$. Since subjective feelings from dry mouth are associated with decreased flow rates of the minor salivary gland, the minor salivary gland flow rate could be used a xerostomia-assessment tool $[25,26]$. Furthermore, minor salivary glands produce saliva during sleep. It appears that a reduced minor salivary gland flow rate could account for dry mouth at night [27]. By secretion of salivary mucins from the minor salivary glands, the formation of a lubricating film on the oral surfaces contributes to mucosal wetting and protection [5]. Minor salivary glands also secrete high concentrations of antibacterial components, such as IgA, to protect the oral mucosa [28]. More than a third of secretory IgA is secreted from the minor salivary glands in whole saliva [29]. Secretory IgA enhances the antibacterial activity of mucin, lactoferrin, peroxidase, and aglutinin [30]. 


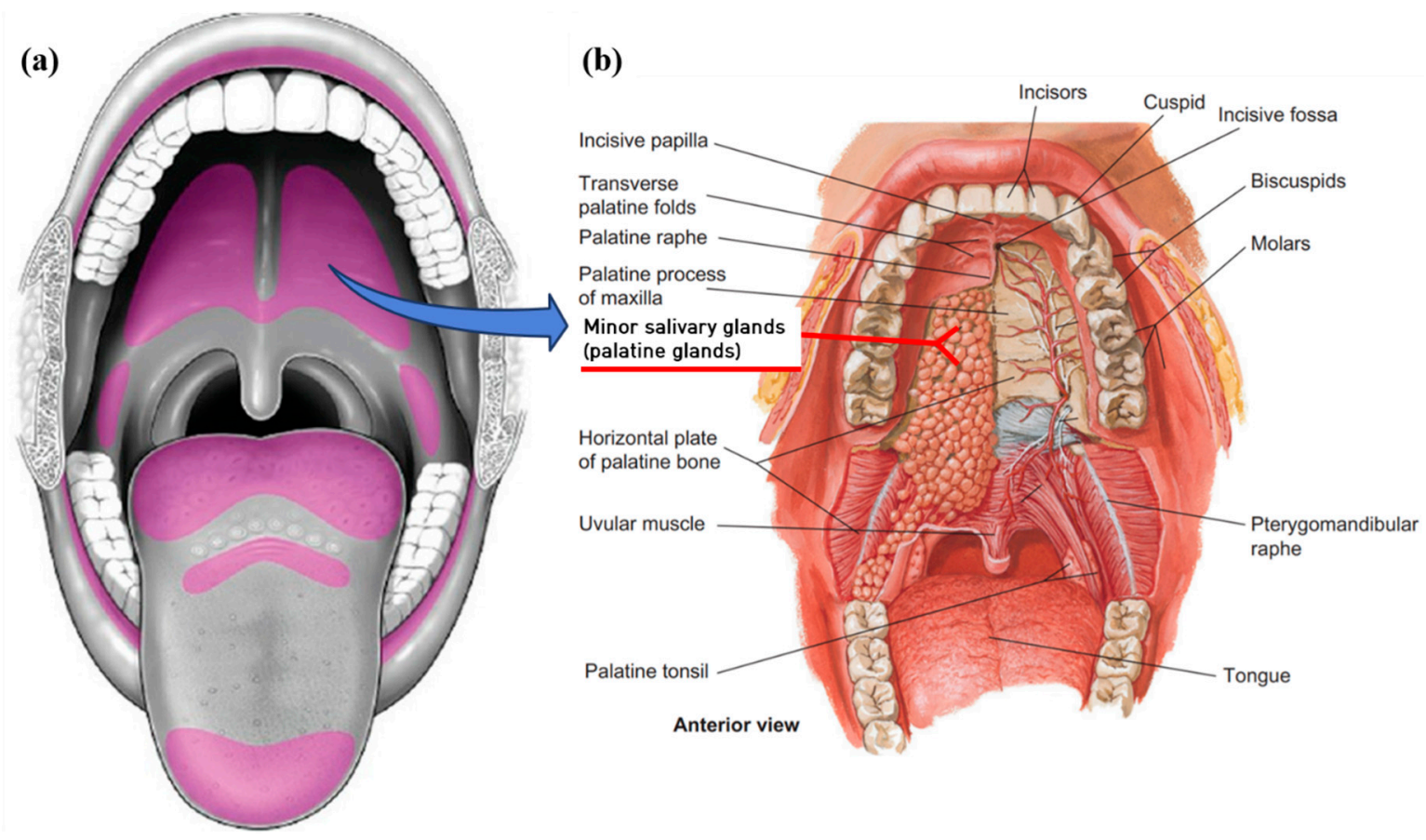

Figure 2. (a) Minor salivary gland distribution in the oral cavity (shown as purple shade). Adapted with permission of Wolters Kluwer Medknow Publications from Review of the Major and Minor Salivary Glands, Part 1: Anatomy, Infectious, and Inflammatory Processes, 8, 1, 2018 [31]. (b) Minor salivary gland are located just below the oral epithelium (Adapted with permission of Elsevier Science and Technology Books from Comparative Anatomy and Histology: A Mouse, Rat, and Human Atlas, 2017 [32]). (a,b) Permission conveyed through Copyright Clearance Center, Inc.

Whole saliva secreted by both major and minor salivary glands is an essential fluid for oral maintenance and function. Saliva initiates the digestive process with digestive enzymes, while simultaneously lubricating the solid diet, to assist with passage through the esophagus. Saliva plays an important role in pronunciation and taste by moisturizing the tongue and other tissues in the mouth. Saliva maintains the acid-base balance of the oral cavity, to protect teeth and soft tissues from prolonged acid exposure due to diet and gastroesophageal reflux $[33,34]$. Additionally, whole saliva contains several signaling molecules essential for the regeneration of oral and esophageal mucosa, including epidermal growth factor, fibroblast growth factor, nerve growth factor, and transforming growth factor alpha. Furthermore, lactoferrin, saliva's Ig, and lysozyme inhibit the progression of oral bacterial or fungal infections [33]. Due to their location directly below the mucosa, the sublingual gland and the minor salivary glands are susceptible to mucosal infection. Therefore, saliva from the major and minor salivary glands prevents oral mucosal diseases, maintains oral hygiene, and lubricates the oral cavity.

\section{Pathology of Salivary Glands}

\subsection{Infectious Diseases Involving Virus, Bacteria, and Fungi}

\subsubsection{Viral and Bacterial Infectious Diseases}

Salivary gland tissue may become infected with numerous viruses and bacteria, thus increasing the susceptibility of candidiasis. Epidemic parotitis is caused by the Paramy $x$ ovirus (mumps is the most common infection) and develops parotid edema with systemic symptoms, including fever, anorexia, malaise, and headache [35]. HIV infects the parotid gland and can lead to the formation of benign lymphoepithelial cystic lesions. Coxsackie virus and Hepatitis $C$ virus are RNA-bound viruses that can infect the salivary glands and damage host tissues, causing dry mouth [35]. Cytomegalovirus (CMV) is a widespread virus with symptoms ranging from asymptomatic to severe-end organ dysfunction. Human CMV infection, usually affecting salivary glands, could be asymptomatic in healthy people, 
or it could be a life-threatening viral infection to immunocompromised individuals [36]. Recent evidence suggests that salivary glands are a potential target of severe acute respiratory syndrome coronavirus 2 (SARS-CoV-2) infection [37]. The study explains that SARS-CoV-2 infection was found in the salivary glands by identifying the presence of angiotensin I-converting enzyme 2 and cellular protease transmembrane serine protease 2 in the salivary glands [38]. Furthermore, many researchers reported sialadenitis by SARSCoV-2 infection and the importance of saliva as a diagnostic tool [39-41]. In minor salivary glands, various viral infections also have been reported, such as Epstein-Barr virus, HIV, and human T-lymphotropic virus [42-44].

Bacterial infections are comparatively rare to viral infections. These infections are caused by either a ductal obstruction or a retrograde spread of infection up the duct secondary to decreased salivary flow. Salivary gland bacterial infections develop in patients who have existing conditions, including postoperative recovery, diabetes or immunodeficiency. Radiation therapy or antidepressant medication could reduce salivary flow and consequently induce staphylococcal and streptococcal strains associated with the biofilm on oral mucosa to infect the salivary gland [20]. Untreated bacterial infections could spread beyond the glandular borders and extend between the neck muscles, leading to serious complications, such as sepsis. In attempt to combat bacterial infection, immune cells infiltrate into the salivary gland and may destroy the secretory system resulting in dry mouth, local pain, and edema [45]. Mycoplasma infection affecting the minor salivary glands has been reported to damage the ductal epithelium, disrupt acinar structures, and cause mucus outflow into connective tissue [46]. Salivary gland dysfunction and destruction caused by various viral and bacterial infection can create a vulnerable condition that causes Candida infection in the oral mucosa and even in the salivary glands.

\subsubsection{Infectious Diseases with Candida}

A study reported that Candida infection of the parotid gland among healthy adults was caused by deep wounds from dentures [47]. Importantly, dentures were found to disrupt the epithelial barrier and induce Candida infection, infiltrating below the mucous membrane. Although fungal infection is reported less frequently, C. albicans, Histoplasma capsulatum, and Cryptococcus neoformans are the most common causes of sialadenitis, salivary gland inflammation [48-54]. Signs and symptoms of sialadenitis by C. albicans are low grade fever $\left(37.4-37.8^{\circ} \mathrm{C}\right)$, painful inflammatory-mediated swelling, and salivary gland duct discharge [10]. Histopathologically, the pus from the parotid gland demonstrated budding yeast cells. The yeast-like cells were between 2 and $4 \mu \mathrm{m}$ in length within the intra- and extra-cellular space of macrophages [10]. Mostly, salivary gland infection with Candida occurs in individuals with impaired immunity, including persons impacted by HIV / AIDS [55]. Additionally, diabetic patients were reported to have increased susceptibility to Candida associated parotitis $[10,48]$.

\subsection{Non-Infectious Inflammatory Disease}

Sjögren's syndrome is an autoimmune disorder that causes chronic inflammation and fibrosis of the salivary glands. The primary presenting symptoms of Sjögren's syndrome are dry eyes and mouth. A study reported that Sjögren's syndrome is associated with the IgG4 spectrum of disease [46]. As the disease progresses and becomes chronic, salivary glands show atrophy, parenchymal calcification, fat replacement, cystic destruction, or multiple lymphocyte cysts [47]. Chronic Sjögren's sialadenitis demonstrates ductal stenosis and swelling using sialography [56]. Chronic sclerosis sialadenitis, also known as Küttner's tumor, indicates chronic enlargement of the salivary glands caused by immune-mediated infiltration of lymphoplasmacytic cells [57]. Remarkably, recent works in the literature have shown strong associations with IgG4-related plasma cell infiltration in over $90 \%$ of patients with chronic sclerosing sialadenitis [58]. Mikulicz disease's cause is unknown, but it is believed to be autoimmune. The disease resembles Sjögren's syndrome except the fact that salivary and lacrimal secretion is less than that of Sjögren's syndrome [20]. Sarcoidosis 
is an autoimmune disease of unknown etiology and can affect multiple systems of the body. Large granulomas can develop in the salivary glands. The granulomas appear as masses with several non-cavity characteristics [45]. The loss of salivary function associated with these inflammatory diseases may cause consequent Candida infection.

\subsection{Secondary Candida Infection with Salivary Gland Tumors}

Salivary gland tumors are often manifested as painless, slow growing, and benign. However, $20 \%$ of salivary gland tumors are diagnosed as malignant tumor. Salivary gland tumors are indicated to be benign in $85 \%$ of tumors affecting the parotid, $60 \%$ of tumors affecting the submandibular, $50 \%$ of tumors affecting the minor glands, and only $10 \%$ of tumors affecting the sublingual glands [59]. Several studies have reported the association between Epstein-Barr virus infection and salivary gland neoplasm. Epstein-Barr virus may be a major factor in its etiology or pathogenesis [55,60-62]. HIV infection was also found to increase the risk of salivary gland cancers. Salivary gland neoplasms, such as adenoid cystic carcinoma, Kaposi sarcoma, and lymphoma, are reported in HIV infection [63].

Candida infection associated with salivary gland neoplasm has been rarely reported. However, Candida infection in the development of squamous cell carcinoma has been suspected for years. Common sites for oral squamous cell carcinoma to develop are on the tongue, lips, and floor of the mouth, where minor salivary glands and sublingual and submandibular glands are distributed. Candida species are more prevalent in potentially malignant oral mucosa diseases and cancerous oral mucosa lesions than in mucosa with the non-cancerous diseases [64,65]. With Candida infection, the rate of malignant transformation in leukoplakia is higher than in leukoplakia without candidiasis. The susceptibility to Candida infection often relies on an imbalance between Candida virulence factors and the host's defensive immune system [66]. In order for C. albicans to penetrate into mucosa, cell surface proteins, called adhesins, must recognize host molecules and adhere to the host cell. After they adhere to the cell surface, the cellular phenotype converts from yeast form to hyphae form by two mechanisms. The first mechanism is the secretion of a protease, a degrading enzyme that can digest epithelial cell surface components. This, in turn, allows physical migration into/between epithelial host cells. The second mechanism is the epithelial cell endocytosis of $C$. albicans. During this process, Candida can damage the host epithelium and the host's immune system [19,66,67]. Furthermore, Candida can produce carcinogenic compounds, nitrosamines, N-nitrosobenzylmethylamine. Strains with high nitrosamines were isolated from lesions with advanced precancerous changes. In such cases, the yeast cells expand from the mucosal surface toward epithelial cells that exhibit the ability to transport and deposit precursors, nitrosamines, into the deep layer, leading to epithelial dysplasia [65]. An in vivo study reported the carcinogenic susceptibility of salivary glands to nitrosamine [68]. It has also been reported that the workers exposed to nitrosamine have a higher mortality rate from salivary gland carcinoma [69].

\section{Candida Infection and Salivary Gland Function}

\subsection{Candida Infection Affecting Salivation}

In the early stages of oral candidiasis, Candida attaches to the oral mucosa and begins to multiply $[64,70]$. Several proteins, such as secretory IgA, lactoferrin, histatins, and defensins, downregulate adhesion and multiplication of Candida [10,71-73]. Among the proteins, histatins and defensins are particularly effective as antifungal factors, which are produced in epithelial cells and salivary glands [74]. Histatins 1,3, and 5 are present within saliva, accounting for about $80 \%$ of total salivary histatins [75]. Human $\beta$-defensin- 1 was isolated from both the major and minor salivary glands, especially from ductal cells and not acinar cells [76]. Therefore, when salivation or the antifungal agent levels of saliva are reduced, oral microbial hyperproliferation is permitted and oral candidiasis can more easily manifest [73].

Salivary flow showed a significantly negative correlation between stimulated salivary flow rates and Candida colony-forming units (CFUs) in the patients with xerostomia [77]. 
This trend also appeared in patients with reduced salivation after radiation therapy [78]. Antifungal therapy for candidiasis patients can expect to relieve pain, redness, and oral mucosa atrophy. Notably, antifungal therapy often increases the amount of saliva by removing Candida. A clinical study investigated the effects of Candida elimination on stimulating whole salivary flow rate [79]. The patients with successful elimination of Candida showed significantly increased stimulated whole salivary flow rate, whereas patients with unsuccessful elimination of Candida did not show increased stimulated whole salivary flow rate. Sympathetic stimuli, like acute pain and stress from Candida infection, can reduce salivary flow rate. In other words, parasympathetic stimuli result in increased saliva flow rate; on the other hand, sympathetic stimuli result in more viscous saliva secretions $[24,80]$. On the basis of this evidence, researchers have suggested that the increased stimulated whole salivary flow rate after treatment was the result of reduced sympathetic stimulation by oral pain reduction [79]. The study states that a decrease in sympathetic stimulation could lead to changed watery salivary secretion. However, $13.5 \%$ of the patients with successful elimination of Candida did not show increased stimulated whole salivary flow rate [79]. The unrestored salivary flow rate may be a result of salivary gland destruction from the Candida infection, and the salivary glands could not restore function even after successful Candida treatment [20,62].

\subsection{Candida Infection and Host Immune Response}

Oral Candida infection on salivary glands causes host immune responses by activation of $\mathrm{T}$ lymphocytes. The $\mathrm{T}$ cells mediate inflammation by stimulating the production of inflammatory cytokines, such as TNF- $\alpha$, IL-1ß, and IL- 6 . These T cells also stimulate the production of inflammatory chemokines and recruit neutrophils and macrophages. The rapid and localized induction of these cytokines form the first line of defense that limits the transmission of invading Candida. However, recurrent or chronic infections can provide an elevated inflammatory environment, leading to organ dysfunction [81]. TNF- $\alpha$ and IL-1ß play well-known roles in the pathogenesis of chronic inflammatory diseases. These cytokines may affect salivary gland damage [82-84]. The role of these cytokines in the etiology has been determined experimentally in Sjögren's syndrome with dry mouth [85]. TNF- $\alpha$ suppresses the transcription of Aquaporin- 5 and destroys human salivary gland acinar cells. Aquaporin-5 is critical for saliva production and a specific channel protein found in the acinar cells that allows for rapid transcellular migration of water in response to an hydrostatic/osmotic pressure gradient $[86,87]$. There is a cycle of destruction where Candida causes immune mediated salivary gland destruction, following reduced salivary flow and consequent Candida infection.

\section{Diagnosis of Oral Candidiasis}

\subsection{Tentative Diagnosis Using Clinical Features and Characteristics}

The diagnosis of oral candidiasis can usually be made through a complete medical history and physical examination [88]. Most commonly, candidiasis demonstrates as acute pseudomembranous candidiasis, acute atrophic candidiasis, chronic atrophic candidiasis, chronic hyperplastic candidiasis, angular cheilitis, or median rhomboid glossitis (Figure 3) [89]. (a) Pseudomembranous candidiasis accounts for approximately $35 \%$ of oral candidiasis cases. In these cases, the pseudomembrane can be easily removed, revealing underlying mucosa, with minimal bleeding. The pseudomembranous white matter consists of debris, fibrin, and exfoliated epithelium invaded by Candida and its hyphae. Acute pseudomembranous candidiasis can be chronic, either intermittently or constantly affecting the patient. The condition may occur in infants, immune-compromised patients (leukemia and AIDS), or patients taking medication such as antibiotics, immunosuppressants, or topical corticosteroids $[18,90,91]$. (b) Acute atrophic candidiasis, also known as erythema candidiasis, is usually associated with a burning sensation in oral mucosa. It presents as a raw-looking red lesion and occurs prior to the formation of the pseudomembrane or appears after the removal of the pseudomembrane. Acute atrophic candidiasis usually occurs 
on the dorsal surface of tongue and is characterized by absent papilla due to the use of topical antibiotics or systemic long-term corticosteroids or antibiotics [18,90,91]. (c) Chronic atrophic candidiasis, referred to AS "denture stomatitis", is usually associated with wearing dentures and inhibited salivary flow. It appears as erythematous inflammation and edema in denture occluded areas. These lesions are caused by dentures rubbing against the oral mucosa, creating a moist and warm environment that is ideal for the growth of Candida. Chronic atrophic candidiasis can be symptomatic, causing soreness and burning, or asymptomatic and only found on routine examination [92,93]. (d) Chronic hyperplastic candidiasis is a rare type of oral candidiasis and appears as a rough or nodular lesion, which complicates the diagnosis by differentiating from oral cancer. It typically appears as white patches on the commissures of the oral mucosa. The main cause of chronic hyperplastic candidiasis is C. albicans, but other systemic co-factors, such as vitamin deficiency and generalized immune suppression, may contribute. Clinically, the lesions are asymptomatic and regress after proper antifungal treatment and correction of underlying nutritional deficiencies or other co-factors. If the lesion is not treated, it can develop into dysplasia or carcinoma [94]. (e) Candida-associated angular cheilitis is inflammatory fissures that emanate from the commissure of the mouth. Angular cheilitis is frequently found in the clinic, including cases involving a combination of Candida and bacterial organisms. Signs and symptoms may include bleeding, blisters, cracks, crusts, itchiness, pain, redness, and swelling. Predisposing factors can be loss of vertical height in the denture wearer, habitual lip licking, mouth breathing, or nutritional deficiencies, particularly with vitamin B12 or iron [95]. (f) Median rhomboid glossitis is a term used to describe the area of a smooth, red, flat, or raised nodule in the middle of the dorsal surface of the tongue. The affected area of the tongue usually does not have a normal coating of filiform papilla covering the entire upper surface of the tongue. High levels of Candida can be discovered from these lesions, which are associated with the frequent use of steroid inhalers or cigarettes [18,90,91].

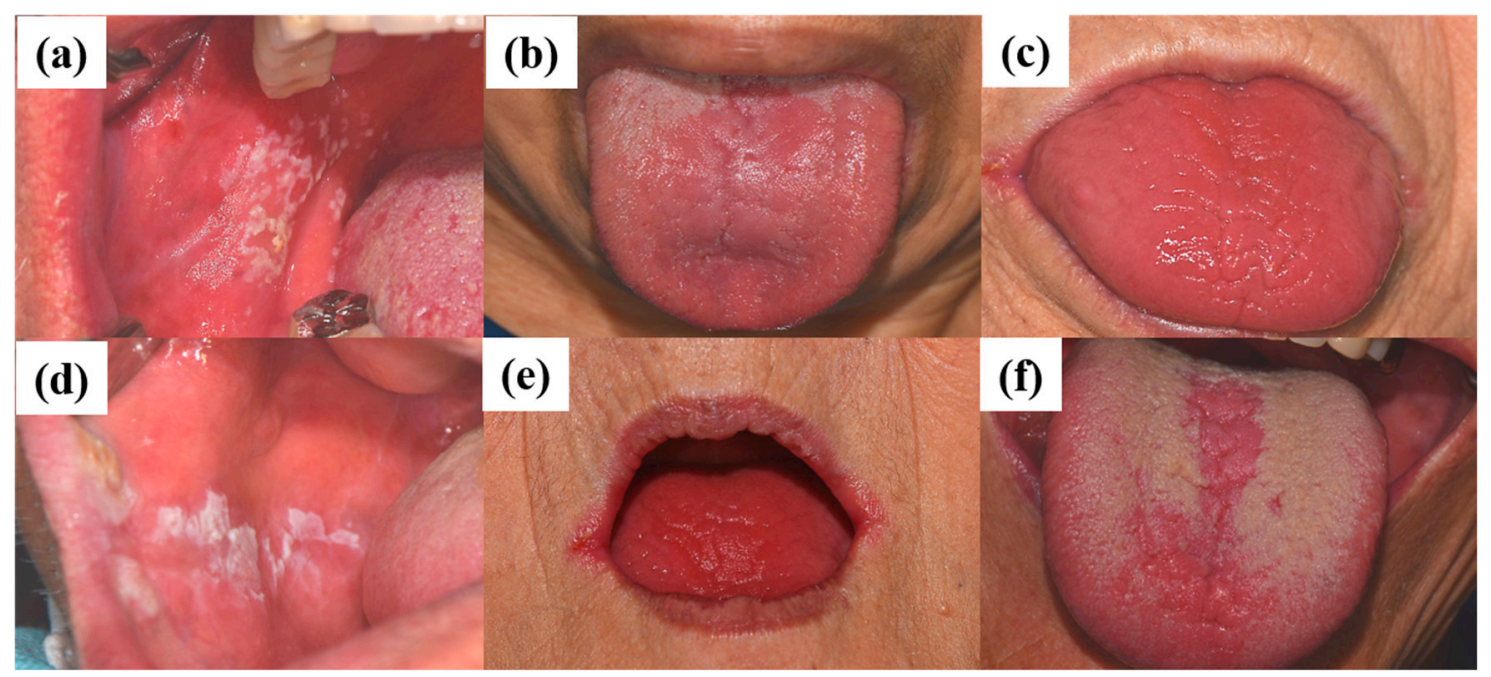

Figure 3. Clinical manifestations of oral candidiasis: (a) acute pseudomembranous candidiasis, (b) acute atrophic candidiasis, (c) chronic atrophic candidiasis, (d) chronic hyperplastic candidiasis, (e) angular cheilitis, and (f) median rhomboid glossitis. Clinical photographs were taken under patients' informed-consent agreement, with approved Institutional Review Board, PNUDH-2017-026, from the Pusan National University Dental Hospital.

\subsection{Definite Diagnosis Using Cytology and Culture}

Diagnosis can be confirmed by smear, oral rinse sample, whole saliva sample, culture, or oral biopsy [88]. Specimens for cytology can be obtained by scraping the lesion with a tongue blade. PAS staining of specimens reveals the existence of Candida hyphae and budding yeast. Moreover, $10 \%$ potassium hydroxide $(\mathrm{KOH})$, gram, and methylene blue staining can be used instead of PAS. The sensitivity of smear is $51.6 \%$, which is less 
than that of sample (oral rinse or whole saliva sample) culture. Candida species at a low concentration of 200 to 500 cells per milliliter of saliva could be detected using cell culture method rather than cytology method. Of the asymptomatic healthy population carry Candida in the oral cavity. Therefore, it is necessary to identify a threshold amount of Candida species ( $>270 \mathrm{CFU} / \mathrm{mL}$ ), to distinguish oral candidiasis from oral carriage [96]. A definitive diagnosis of candidiasis requires the confirmation of tissue invasion by Candida, using biopsy with PAS staining. Biopsies are always required in hyperplastic candidiasis in order to discard the existence of epithelial dysplasia [97].

\section{Prevention and Treatments of Oral Candidiasis}

\subsection{Prevention}

Clinicians should notice that patients with immunocompromised disease, such as AIDS and diabetes, or individuals who have the risk factors of usage of medication (antibiotics, steroids, or immunosuppressants), impaired salivary gland function, dentures, poor oral hygiene, or a high-carbohydrate diet can develop candidiasis easily. Therefore, periodical oral examinations, oral hygiene instruction, and periodic prophylaxis could prevent oral candidiasis. Oral hygiene includes cleaning the tongue with a tongue cleaner, cleaning teeth and dentures with a toothbrush [98], and rinsing oral mucosa with chlorhexidine. In addition, dentures should be removed at night and meticulously washed and soaked in a disinfectant solution, such as chlorhexidine and sodium hypochlorite (1\%) [15,99]. To reduce the destruction of salivary glands due to repetitive candidiasis, periodical oral examinations with prophylaxis and proper oral hygiene instruction should be recommended and practiced.

\subsection{Treatments of Candida Infection}

The treatment of oral candidiasis is based on four basic principles [98,100]: Assess the Candida infection type, diagnose the infection early and accurately, correct the predisposing factor or underlying disease, and administer antifungal agents appropriately. In order to select the proper medications, studies consider factors including local or systematic approach, type of Candida, clinical findings [90], and medication efficacy and toxicity [101]. Commonly used antifungal medications are included in Table 1.

Table 1. Summary of the antifungal medications and their side effects.

\begin{tabular}{cccc}
\hline Drug & Formulation & Dose & Side Effect \\
\hline \multirow{2}{*}{ Amphotericin B } & Infusion $50 \mathrm{mg}$ & $100-200 \mathrm{mg} / 6 \mathrm{~h}$ & Renal, cardiovascular, spinal, and neurological \\
\hline \multirow{2}{*}{ Nystatin } & Suspension $60 \mathrm{~mL}$ & $4-6 \mathrm{~mL} / 6 \mathrm{~h}$ & Well tolerated \\
\cline { 2 - 4 } & Ointment $30 \mathrm{~g}$ & $2-4$ times $/$ day & \\
\cline { 2 - 4 } Miconazole & Tablets & 2 every $8 \mathrm{~h}$ & Uncommon nausea, vomiting, and gastrointestinal effects \\
\hline \multirow{2}{*}{ Ketoconazole } & Gel $1 \%$ & 3 times $/$ day & Occasionally skin irritation and burning sensation. \\
\cline { 2 - 4 } & Tablets $10 \mathrm{mg}$ & 5 times /day & Uncommon burning, irritation, nausea, and diarrhea. \\
\cline { 2 - 4 } & Gel & $100 \mathrm{mg} / 6 \mathrm{~h}$ & Nausea, vomiting \\
\hline \multirow{2}{*}{ Fluconazole } & Tablets & 3 times $/$ day & abdominal pain. \\
\cline { 2 - 4 } & Suspension $30 \mathrm{~mL}$ & $200 \mathrm{mg}, 1-2 /$ day & Nausea, vomiting, diarrhea, and abdominal pain. \\
\hline Itraconazole & Tablets & $50-100 \mathrm{mg} /$ day & \\
\hline
\end{tabular}

Table was adapted with permission of CEDRO, Centro Espanol de Derechos Reprograficos, from “Current treatment of oral candidiasis: A literature review", 6, 5, 2014 [98]); permission conveyed through Copyright Clearance Center, Inc. (Danvers, MA, USA). 
Based on the histopathological information via microscopic examination and fungal culture, clinicians should choose the most appropriate antifungal medication. Polyene was the first broad spectrum antifungal agent discovered in the 1940s and 1950s [102]. Polyenes, such as nystatin and amphotericin B, bind to and weaken ergosterols in fungal cell membranes that can initiate the leakage of $\mathrm{K}+$ and $\mathrm{Na}+$ ions, thus contributing to fungal cell death. Polyenes are considered fungicidal and have broad activity against most fungal organisms. Amphotericin B is an antifungal drug used for serious fungal infections and nystatin is used to treat Candida infections of the skin, vagina, mouth, and esophagus $[102,103]$. Although resistance to polyene medication is rare, some fungal species exhibit intrinsic resistance to polyenes $[104,105]$. Nystatin is only effective topically, and amphotericin B, which is effective orally and intravenously, is well-known for its severe and potentially lethal side effects such as high fever, kidney damage, and multiple-organ damage. The search for antifungal agents with an acceptable toxicity profile first led to the discovery of azole. Therefore the first azoles were discovered in 1944, but were not approved for use in humans until the early 1960s [102]. Azoles inhibit 14- $\alpha$-sterol demethylase, a cytochrome P-450 enzyme involved in ergosterol synthesis [106], resulting in the accumulation of toxic sterol intermediaries and loss of membrane integrity. Most azoles are fungistatic and have a broad spectrum against filamentous fungi and yeasts $[107,108]$. The search for azole antifungal agents with an acceptable toxicity profile led to the discovery of the first ketoconazole. Later, the triazoles fluconazole and itraconazole were developed with an improved safety profile and comparatively broader range of antifungal activity. Analogs have been developed to overcome limitations, such as a suboptimal spectra of activity, need to develop resistance, unfavorable pharmacokinetics, drug-drug interactions, and toxicity [109]. Candida species resistance to the azole medications (e.g., itraconazole, clotrimazole, and fluconazole), including Candida glabrata, Candida tropicalis, or Candida parapsilosis are susceptible to polyene medication. Polyene medications are not well absorbed from the gastrointestinal tract but are effective for topical application [89]. Topical antifungal therapy is recommended as the primary treatment option for mild cases of Candida infection. If the lesion is refractory to topical treatment or recurs frequently, systemic antifungal therapy is suggested. However, systemic antifungal therapy must be considered as the primary treatment for patients with immunocompromised conditions due to the risk of candidemia [103].

The removal of Candida biofilm is necessary, in combination with appropriate medication. Successful treatment of candidiasis depends upon biofilm control, using daily oral hygiene and professional prophylaxis. The Candida biofilm is a thick extracellular polymeric substances layer with a dense network of yeasts, pseudohyphae, and hyphae [110]. The biofilm allows Candida to easily attach between cells and other surfaces, such as dentures. The biofilm provides barriers between Candida and the surrounding environment, thus protecting Candida from antifungal medications [90]. Therefore, the removal of Candida biofilm from the dentures, as well as from all sides of the oral cavity, contributes to lowering the failure rate of antifungal treatment; it is essential for the effective treatment of Candida infection.

\subsection{Treatments of Salivary Gland Dysfunction \\ 6.3.1. Symptomatic Management}

Hyposalivation is symptomatically managed with methods such as lifestyle changes, synthetic saliva supplementation, salivary gland stimulants, and the use of sialagogues (e.g., muscarinic receptor agonists, pilocarpine, and sevimeline) to elevate the flow rate of saliva [111,112]. Among the sialagogue treatment options, pilocarpine is the most commonly selected medication to increase saliva secretion by stimulating the salivary gland. However, pilocarpine's effect is temporary and causes side effects, including excessive sweating and tearing, chills, dizziness, flushing, nasal congestion, vocal changes, nervousness, tremors, and diarrhea $[113,114]$. To improve the side effects of pilocarpine, consistent and controlled release of pilocarpine in the salivary glands was considered [115]. Controlled 
drug-release systems have been developed and are expected to deliver therapeutic agents directly to salivary glands using novel biomedical approaches, such as hydrogels [116], polymer-based microchips [117], nanoshells [118], and microfluidics technology [119]. For example, polymer hydrogels for controlling pilocarpine release have already been clinically tested in patients with Sjögren's syndrome [115]. However, the polymer hydrogel and associated medication could not improve the discomfort of patients who had completely destroyed acinar cells. Since the severity of salivary dysfunction may vary from patient to patient [115], the literature suggests that the most effective therapy depends on the evaluation of salivary glands damage.

\subsubsection{Gene Therapy and Cellular Stimulation}

Gene delivery therapy could be applied to salivary gland cells to ameliorate salivary gland function. Loss of functional water channels in salivary gland epithelia is often considered one of the hallmarks of salivary gland dysfunction, and recent advances are aimed at restoring the permeability in an attempt to increase saliva production. Gene therapy was attempted to deliver the human aquaporin 1 (AQP1) gene to the salivary gland via recombinant adenovirus delivery (AdhAQP1) in rats [120]. The result suggests that AQP1 gene transfer may have potential as an approach for the treatment of salivary hypofunction. In the human study, five of 11 patients experienced elevated salivary flow 3-4.7 years after the AdhAQP1 vector delivery treatment [121]. Clinically, gene delivery to salivary glands offers the accessibility of transfer vectors in a less invasive manner [122]. The administration of bioactive components, cells, and genes directly into the salivary gland is a promising therapeutic option, when salivary-gland cells are intact. Systemic and local delivery was performed to administer a multitude of reagents, including adenoviral vectors, primary cells, growth factors, antioxidant compounds, and cytokines [123-129]. In addition, bone-marrow-derived cell (BMC) recruitment by cytokine stimulation has been reported for recovery of salivary gland cells in vivo [130,131]. Studies demonstrate that subcutaneous injection of granulocyte colony stimulating factor mobilized BMC into the bloodstream and induced migration of BMC to the damaged salivary gland, resulting in improvement of morphology and function of the submandibular salivary gland [130].

\subsubsection{Stem Cell Therapy}

Among the stem cell approaches, a majority of research relies on mesenchymal stem cells (MSCs) [132,133]. In the MSC salivary transplant in vivo studies, MSCs have been acquired from bone marrow, adipose tissue, or umbilical cord blood [132,134,135]. MSCs are able to be harvested in a non-invasive manner, with relative abundance. Although the differentiation of MSCs into salivary gland acinar cells has been observed in vitro, the actual contribution to differentiation in vivo is unclear and controversial. Their beneficial action can occur primarily through paracrine pro-survival/proliferative effects on the remaining local stem/progenitor cells and cells of the surrounding environment $[136,137]$. However, MSCs have primary safety concerns, including unknown long-term report, tumorigenic, and metastatic potential. In addition, donor-dependent efficacy and heterogeneous properties of MSCs pose critical obstacles [138]. Therefore, autologous stem cells are preferred to repair salivary gland function. Transplantation of pluripotent salivary gland-specific epithelial stem/progenitor cells has been shown to morphologically and functionally repair salivary gland tissues. Multi-level of potency from the salivary gland cells could be applied to repair compartments of the salivary gland, recover the secretory compartment conditions, and maintain the secretory compartment $[139,140]$. Permanently differentiated and post-mitotic acinar cells may be able to self-duplicate after damage in post-chronic sialadenitis [141], post-duct ligation [142], partial salivary gland excision [143], and post-radiation therapy. In fact, most patients requiring autologous cell therapy are elderly and do not have enough stem/progenitor cells [144,145]. Although the number of stem/progenitor cells was increased by using heparin sulfate-stimulated growth factors [146] or Aldehyde dehydrogenase-3 activator [147], the absolute number 
of stem/progenitor cells required for functional regeneration of the human gland has not been clearly defined.

\subsubsection{Tissue Engineering}

In cases of full destruction of salivary glands, it is insufficient to restore part of the damaged salivary glands and their function. To achieve a complete functional replacement of lost or damaged tissue, tissue-engineered organoids to reconstruct fully functional organs has been proposed $[148,149]$. In vitro tissue-engineered organoids, using threedimensional biomaterials loaded with salivary gland cells and/or bioactive cues, can be embedded in extracellular matrix to connect with remaining tissue residues. This approach, called the "organ germ method", has been evaluated for the regeneration of fully functional salivary glands in mice, which has been induced by mutual epithelial and mesenchymal interactions [149]. The bioengineered salivary gland responded to pilocarpine administration and taste stimulation by producing saliva. To be utilized in clinical practice, an appropriate cell source needs to be clearly identified. Recently, induced pluripotent stem cells or embryonic stem cells have been studied in salivary-gland tissue engineering [150].

Although notable progress in the treatment of hypofunctional salivary gland has been attempted over the last decades, no definitive treatment has been confirmed. Limitations of in vivo studies for translation to human trial are present due to the biological differences between human and rodent salivary glands and require further study [140]. In addition, potential differences in the development and/or regeneration strategies between different glands (e.g., parotid, submandibular, and sublingual) should be considered for future translation.

\section{Conclusions}

A mutual vicious cycle presents itself between the salivary gland and Candida infection: A decrease in the saliva flow rate creates conditions that encourage Candida infections, and then the Candida infection damages salivary glands, leading to a further decrease in saliva secretion. This pathological malfunction could result in temporary or permanent destruction of the salivary glands and may cause various intraoral symptoms, including dry mouth, speech and swallowing difficulties, and oral infections. Oral candidiasis should be detected early and treated correspondently, using an antifungal agent like nystatin and fluconazole to prevent the development of chronic salivary gland dysfunction. Correction of the underlying disease, biofilm control by using tongue cleaners, and chlorhexidine rinses must be accompanied. Limitation of current treatment options of salivary gland dysfunction are symptomatic management with medication with their side effects. Therefore, scientists have made an effort to regenerate salivary glands, using various sources to overcome the limitations of current treatments. Regeneration of salivary glands has been attempted by the activation of remaining cells with growth factors, genes, cytokines, and the transplantation of progenitor cells and mesenchymal stem cells. However, these technologies are still limited in clinical application and are in a stage that requires further research. Therefore, the clinician's role in the early detection and proper treatment of vulnerable populations who could be exposed to Candida-mediated salivary gland dysfunction is important.

Author Contributions: Conceptualization, Y.-W.A., H.-M.J., S.-H.J., S.-M.O., and K.C.; methodology, Y.-W.A., H.-M.J., S.-H.J., S.-M.O., and K.C.; writing-original draft preparation, D.H., T.L., S.-M.O., and K.C.; writing-review and editing, Y.-W.A., H.-M.J., S.-H.J., D.H., T.L., S.-M.O., and K.C.; supervision, K.C.; project administration, S.-M.O. and K.C. All authors have read and agreed to the published version of the manuscript.

Funding: This work was supported by the National Research Foundation of Korea (NRF) grant funded by the Korea government (MSIT) (NRF-2020R1F1A1049150). 
Institutional Review Board Statement: The study was conducted according to the guidelines of the Declaration of Helsinki, and approved by the Institutional Review Board of Pusan National University Dental Hospital (protocol code PNUDH-2017-026 and date of approval 21 December 2017).

Informed Consent Statement: Informed consent was obtained from all subjects involved in the study. Data Availability Statement: Data sharing not applicable.

Conflicts of Interest: The authors declare no conflict of interest.

\section{References}

1. Hellquist, H.; Skalova, A. Histopathology of the Salivary Glands; Springer: Berlin/Heidelberg, Germany, 2014.

2. Aframian, D.J.; Keshet, N.; Nadler, C.; Zadik, Y.; Vered, M. Minor salivary glands: Clinical, histological and immunohistochemical features of common and less common pathologies. Acta Histochem. 2019, 121, 151451. [CrossRef] [PubMed]

3. Amano, O.; Mizobe, K.; Bando, Y.; Sakiyama, K. Anatomy and histology of rodent and human major salivary glands: -Overview of the Japan salivary gland society-sponsored workshop-. Acta Histochem. Cytochem. 2012, 45, 241-250. [CrossRef] [PubMed]

4. Hand, A.R.; Pathmanathan, D.; Field, R.B. Morphological features of the minor salivary glands. Arch. Oral Biol. 1999, 44 (Suppl. S1), S3-S10. [CrossRef]

5. Won, S.; Kho, H.; Kim, Y.; Chung, S.; Lee, S. Analysis of residual saliva and minor salivary gland secretions. Arch. Oral Biol. 2001, 46, 619-624. [CrossRef]

6. Rayment, S.A.; Liu, B.; Offner, G.D.; Oppenheim, F.G.; Troxler, R.F. Immunoquantification of human salivary mucins MG1 and MG2 in stimulated whole saliva: Factors influencing mucin levels. J. Dent. Res. 2000, 79, 1765-1772.

7. Smith, D.J.; Joshipura, K.; Kent, R.; Taubman, M.A. Effect of age on immunoglobulin content and volume of human labial gland saliva. J. Dent. Res. 1992, 71, 1891-1894. [CrossRef]

8. Rudney, J.D.; Krig, M.A.; Neuvar, E.K.; Soberay, A.H.; Iverson, L. Antimicrobial proteins in human unstimulated whole saliva in relation to each other, and to measures of health status, dental plaque accumulation and composition. Arch. Oral Biol. 1991, 36, 497-506. [CrossRef]

9. Skinner, C.E.; Fletcher, D.W. A review of the genus candida. Bacteriol. Rev. 1960, 24, 397-416. [CrossRef]

10. Enache-Angoulvant, A.; Torti, F.; Tassart, M.; Poirot, J.-L.; Jafari, A.; Roux, P.; Hennequin, C. Candidal abscess of the parotid gland due to Candida glabrata: Report of a case and literature review. Med. Mycol. 2010, 48, 402-405. [CrossRef]

11. Edgerton, M.; Koshlukova, S.E. Salivary histatin 5 and its similarities to the other antimicrobial proteins in human saliva. Adv. Dent Res. 2000, 14, 16-21. [CrossRef]

12. Tsui, C.; Kong, E.F.; Jabra-Rizk, M.A. Pathogenesis of Candida albicans biofilm. Pathog. Dis. 2016, 74, ftw018. [CrossRef] [PubMed]

13. Reichart, P.A.; Samaranayake, L.P.; Philipsen, H.P. Pathology and clinical correlates in oral candidiasis and its variants: A review. Oral Dis. 2000, 6, 85-91. [CrossRef] [PubMed]

14. Muadcheingka, T.; Tantivitayakul, P. Distribution of Candida albicans and non-albicans Candida species in oral candidiasis patients: Correlation between cell surface hydrophobicity and biofilm forming activities. Arch. Oral Biol. 2015, 60, 894-901. [CrossRef] [PubMed]

15. Akpan, A.; Morgan, R. Oral candidiasis. Postgrad. Med. J. 2002, 78, 455-459. [CrossRef] [PubMed]

16. Barnett, J.A. A history of research on yeasts 12: Medical yeasts part 1, Candida albicans. Yeast 2008, 25, 385-417. [CrossRef] [PubMed]

17. Scully, C. Oral and Maxillofacial Medicine: The Basis of Diagnosis and Treatment, 2nd ed.; Elsevier: Philadelphia, PA, USA, 2008; pp. 191-200.

18. Lalla, R.V.; Patton, L.L.; Dongari-Bagtzoglou, A. Oral candidiasis: Pathogenesis, clinical presentation, diagnosis and treatment strategies. J. Calif. Dent. Assoc. 2013, 41, 263-268.

19. Vila, T.; Sultan, A.S.; Montelongo-Jauregui, D.; Jabra-Rizk, M.A. Oral candidiasis: A disease of opportunity. J. Fungi 2020, 6, 15. [CrossRef]

20. Ogle, O.E. Salivary Gland Diseases. Dent. Clin. N. Am. 2020, 64, 87-104. [CrossRef]

21. Ochiai, A.; Harada, K.; Hashimoto, K.; Shibata, K.; Ishiyama, Y.; Mitsui, T.; Tanaka, T.; Taniguchi, M. $\alpha$-Amylase is a potential growth inhibitor of Porphyromonas gingivalis, a periodontal pathogenic bacterium. J. Periodontal Res. 2014, 49, 62-68. [CrossRef]

22. Kondo, Y.; Nakamoto, T.; Jaramillo, Y.; Choi, S.; Catalan, M.A.; Melvin, J.E. Functional differences in the acinar cells of the murine major salivary glands. J. Dent. Res. 2015, 94, 715-721. [CrossRef]

23. La'porte, S.J.; Juttla, J.K.; Lingam, R.K. Imaging the floor of the mouth and the sublingual space. Radiographics 2011, 31, 1215-1230. [CrossRef] [PubMed]

24. Iorgulescu, G. Saliva between normal and pathological. Important factors in determining systemic and oral health. J. Med. Life 2009, 2, 303-307.

25. Eliasson, L.; Birkhed, D.; Carlén, A. Feeling of dry mouth in relation to whole and minor gland saliva secretion rate. Arch. Oral Biol. 2009, 54, 263-267. [CrossRef] [PubMed]

26. Bretz, W.A.; Loesche, W.J.; Chen, Y.M.; Schork, M.A.; Dominguez, B.L.; Grossman, N. Minor salivary gland secretion in the elderly. Oral Surg. Oral Med. Oral Pathol. Oral Radiol. Endod. 2000, 89, 696-701. [CrossRef] [PubMed] 
27. Dijkema, T.; Raaijmakers, C.P.J.; Braam, P.M.; Roesink, J.M.; Monninkhof, E.M.; Terhaard, C.H.J. Xerostomia: A day and night difference. Radiother. Oncol. 2012, 104, 219-223. [CrossRef] [PubMed]

28. Eliasson, L.; Carlén, A. An update on minor salivary gland secretions. Eur. J. Oral Sci. 2010, 118, 435-442. [CrossRef] [PubMed]

29. Shern, R.J.; Fox, P.C.; Cain, J.L.; Li, S.H. A method for measuring the flow of saliva from the minor salivary glands. J. Dent. Res. 1990, 69, 1146-1149. [CrossRef] [PubMed]

30. Marcotte, H.; Lavoie, M.C. Oral microbial ecology and the role of salivary immunoglobulin A. Microbiol. Mol. Biol. Rev. 1998, 62, 71-109. [CrossRef]

31. Kessler, A.T.; Bhatt, A.A. Review of the major and minor salivary glands, part 1: Anatomy, infectious, and inflammatory processes. J. Clin. Imaging Sci. 2018, 8, 47. [CrossRef]

32. Treuting, P.M.; Morton, T.H. Oral cavity and teeth. In Comparative Anatomy and Histology; Elsevier: Amsterdam, The Netherlands, 2012; pp. 95-110.

33. Matsuo, R. Role of saliva in the maintenance of taste sensitivity. Crit. Rev. Oral Biol. Med. 2000, 11, 216-229. [CrossRef]

34. Yoshikawa, H.; Furuta, K.; Ueno, M.; Egawa, M.; Yoshino, A.; Kondo, S.; Nariai, Y.; Ishibashi, H.; Kinoshita, Y.; Sekine, J. Oral symptoms including dental erosion in gastroesophageal reflux disease are associated with decreased salivary flow volume and swallowing function. J. Gastroenterol. 2012, 47, 412-420. [CrossRef] [PubMed]

35. Hviid, A.; Rubin, S.; Mühlemann, K. Mumps. Lancet 2008, 371, 932-944. [CrossRef]

36. Gupta, M.; Shorman, M. Cytomegalovirus. In StatPearls; StatPearls Publishing: Treasure Island, FL, USA, 2020.

37. Xu, J.; Li, Y.; Gan, F.; Du, Y.; Yao, Y. Salivary Glands: Potential Reservoirs for COVID-19 Asymptomatic Infection. J. Dent. Res. 2020, 99, 989. [CrossRef]

38. Pascolo, L.; Zupin, L.; Melato, M.; Tricarico, P.M.; Crovella, S. TMPRSS2 and ACE2 Coexpression in SARS-CoV-2 Salivary Glands Infection. J. Dent. Res. 2020, 99, 1120-1121. [CrossRef]

39. Fisher, J.; Monette, D.L.; Patel, K.R.; Kelley, B.P.; Kennedy, M. COVID-19 associated parotitis: A case report. Am. J. Emerg. Med. 2020. [CrossRef]

40. Chern, A.; Famuyide, A.O.; Moonis, G.; Lalwani, A.K. Sialadenitis: A Possible Early Manifestation of COVID-19. Laryngoscope 2020, 130, 2595-2597. [CrossRef]

41. Lechien, J.R.; Chetrit, A.; Chekkoury-Idrissi, Y.; Distinguin, L.; Circiu, M.; Saussez, S.; Berradja, N.; Edjlali, M.; Hans, S.; Carlier, R. Parotitis-Like Symptoms Associated with COVID-19, France, March-April 2020. Emerg. Infect. Dis. 2020, 26, 2270. [CrossRef]

42. Mariette, X.; Gozlan, J.; Clerc, D.; Bisson, M.; Morinet, F. Detection of Epstein-Barr virus DNA by in situ hybridization and polymerase chain reaction in salivary gland biopsy specimens from patients with Sjögren's syndrome. Am. J. Med. 1991, 90, 286-294. [CrossRef]

43. Rivera, H.; Nikitakis, N.G.; Castillo, S.; Siavash, H.; Papadimitriou, J.C.; Sauk, J.J. Histopathological analysis and demonstration of EBV and HIV p-24 antigen but not CMV expression in labial minor salivary glands of HIV patients affected by diffuse infiltrative lymphocytosis syndrome. J. Oral Pathol. Med. 2003, 32, 431-437. [CrossRef]

44. Mariette, X.; Agbalika, F.; Zucker-Franklin, D.; Clerc, D.; Janin, A.; Cherot, P.; Brouet, J.C. Detection of the tax gene of HTLV-I in labial salivary glands from patients with Sjögren's syndrome and other diseases of the oral cavity. Clin. Exp. Rheumatol. 2000, $18,341-347$.

45. Ugga, L.; Ravanelli, M.; Pallottino, A.A.; Farina, D.; Maroldi, R. Diagnostic work-up in obstructive and inflammatory salivary gland disorders. Acta Otorhinolaryngol. Ital. 2017, 37, 83-93. [PubMed]

46. Wray, W.; Scully, C.; Rennie, J.; Mason, D.K.; Love, W.C. Major and minor salivary gland swelling in Mycoplasma pneumoniae infection. Br. Med. J. 1980, 280, 1421. [CrossRef] [PubMed]

47. De Gomes, P.S.; Juodzbalys, G.; Fernandes, M.H.; Guobis, Z. Diagnostic Approaches to Sjögren's syndrome: A Literature Review and Own Clinical Experience. J. Oral Maxillofac. Res. 2012, 3, e3. [CrossRef] [PubMed]

48. Even-Tov, E.; Niv, A.; Kraus, M.; Nash, M. Candida parotitis with abscess formation. Acta Otolaryngol. 2006, 126, 334-336. [CrossRef]

49. Kantarcioğlu, A.S.; Gulenc, M.; Yücel, A.; Uzun, N.; Taskin, T.; Sakiz, D.; Altas, K. Cryptococcal parotid involvement: An uncommon localization of Cryptococcus neoformans. Med. Mycol. 2006, 44, 279-283. [CrossRef]

50. Marioni, G.; Rinaldi, R.; de Filippis, C.; Gaio, E.; Staffieri, A. Candidal abscess of the parotid gland associated with facial nerve paralysis. Acta Otolaryngol. 2003, 123, 661-663. [CrossRef]

51. Namiq, A.L.; Tollefson, T.; Fan, F. Cryptococcal parotitis presenting as a cystic parotid mass: Report of a case diagnosed by fine-needle aspiration cytology. Diagn. Cytopathol. 2005, 33, 36-38. [CrossRef]

52. Stefanopoulos, P.K.; Karakassis, D.T.; Triantafyllidou, A. Stensen's duct obstruction by foreign body and subsequent candidal infection of the parotid gland. J. Laryngol. Otol. 2003, 117, 662-665. [CrossRef]

53. Vargas, P.A.; Mauad, T.; Böhm, G.M.; Saldiva, P.H.N.; Almeida, O.P. Parotid gland involvement in advanced AIDS. Oral Dis. 2003, 9, 55-61. [CrossRef]

54. Souza Filho, F.J.; Lopes, M.; Almeida, O.P.; Scully, C. Mucocutaneous histoplasmosis in AIDS. Br. J. Dermatol. 1995, 133, $472-474$. [CrossRef]

55. De Repentigny, L.; Lewandowski, D.; Jolicoeur, P. Immunopathogenesis of oropharyngeal candidiasis in human immunodeficiency virus infection. Clin. Microbiol. Rev. 2004, 17, 729-759. [CrossRef] 
56. Liang, Y.; Yang, Z.; Qin, B.; Zhong, R. Primary Sjogren's syndrome and malignancy risk: A systematic review and meta-analysis. Ann. Rheum. Dis. 2014, 73, 1151-1156. [CrossRef]

57. Wei, T.-W.; Lien, C.-F.; Hsu, T.-Y.; He, H.-L. Chronic sclerosing sialadenitis of the submandibular gland: An entity of IgG4-related sclerosing disease. Int. J. Clin. Exp. Pathol. 2015, 8, 8628-8631.

58. Geyer, J.T.; Ferry, J.A.; Harris, N.L.; Stone, J.H.; Zukerberg, L.R.; Lauwers, G.Y.; Pilch, B.Z.; Deshpande, V. Chronic sclerosing sialadenitis (Küttner tumor) is an IgG4-associated disease. Am. J. Surg. Pathol. 2010, 34, 202-210. [CrossRef]

59. Speight, P.M.; Barrett, A.W. Salivary gland tumours. Oral Dis. 2002, 8, 229-240. [CrossRef]

60. Venkateswaran, L.; Gan, Y.J.; Sixbey, J.W.; Santana, V.M. Epstein-Barr virus infection in salivary gland tumors in children and young adults. Cancer 2000, 89, 463-466. [CrossRef]

61. Mozaffari, H.R.; Ramezani, M.; Janbakhsh, A.; Sadeghi, M. Malignant Salivary Gland Tumors and Epstein-Barr Virus (EBV) Infection: A Systematic Review and Meta-Analysis. Asian Pac. J. Cancer Prev. 2017, 18, 1201-1206.

62. Raab-Traub, N.; Rajadurai, P.; Flynn, K.; Lanier, A.P. Epstein-Barr virus infection in carcinoma of the salivary gland. J. Virol. 1991, 65, 7032-7036. [CrossRef]

63. Sujatha, D.; Babitha, K.; Prasad, R.S.; Pai, A. Parotid lymphoepithelial cysts in human immunodeficiency virus: A review. J. Laryngol. Otol. 2013, 127, 1046-1049. [CrossRef]

64. Nagao, Y.; Hashimoto, K.; Sata, M. Candidiasis and other oral mucosal lesions during and after interferon therapy for HCV-related chronic liver diseases. BMC Gastroenterol. 2012, 12, 155. [CrossRef]

65. Sankari, S.L.; Gayathri, K.; Balachander, N.; Malathi, L. Candida in potentially malignant oral disorders. J. Pharm. Bioallied Sci. 2015, 7, S162-S164.

66. Archambault, L.S.; Trzilova, D.; Gonia, S.; Gale, C.; Wheeler, R.T. Intravital Imaging Reveals Divergent Cytokine and Cellular Immune Responses to Candida albicans and Candida parapsilosis. MBio 2019, 10. [CrossRef]

67. Ohta, H.; Tanimoto, T.; Taniai, M.; Taniguchi, M.; Ariyasu, T.; Arai, S.; Ohta, T.; Fukuda, S. Regulation of Candida albicans morphogenesis by tumor necrosis factor-alpha and potential for treatment of oral candidiasis. In Vivo 2007, 21, 25-32.

68. Okamura, M.; Moto, M.; Kashida, Y.; Machida, N.; Mitsumori, K. Carcinogenic susceptibility to N-bis(2-hydroxypropyl)nitrosamine (DHPN) in rasH2 mice. Toxicol. Pathol. 2004, 32, 474-481. [CrossRef]

69. Kim, D.; Hwang, Y.-I.; Choi, S.; Park, C.; Lee, N.; Kim, E.-A. A case of tracheal adenoid cystic carcinoma in a worker exposed to rubber fumes. Ann. Occup. Environ. Med. 2013, 25, 22. [CrossRef]

70. Murtaugh, L.C.; Keefe, M.D. Regeneration and repair of the exocrine pancreas. Annu. Rev. Physiol. 2015, 77, 229-249. [CrossRef]

71. Mahalakshmi, S.; Kandula, S.; Shilpa, P.; Kokila, G. Chronic Recurrent Non-specific Parotitis: A Case Report and Review. Ethiop. J. Health Sci. 2017, 27, 95-100. [CrossRef]

72. Tanida, T.; Okamoto, T.; Okamoto, A.; Wang, H.; Hamada, T.; Ueta, E.; Osaki, T. Decreased excretion of antimicrobial proteins and peptides in saliva of patients with oral candidiasis. J. Oral Pathol. Med. 2003, 32, 586-594. [CrossRef]

73. Lynge Pedersen, A.M.; Belstrøm, D. The role of natural salivary defences in maintaining a healthy oral microbiota. J. Dent. 2019, 80 (Suppl. S1), S3-S12. [CrossRef]

74. Ciociola, T.; Giovati, L.; Conti, S.; Magliani, W.; Santinoli, C.; Polonelli, L. Natural and synthetic peptides with antifungal activity. Future Med. Chem. 2016, 8, 1413-1433. [CrossRef]

75. Edgerton, M.; Koshlukova, S.E.; Araujo, M.W.; Patel, R.C.; Dong, J.; Bruenn, J.A. Salivary histatin 5 and human neutrophil defensin 1 kill Candida albicans via shared pathways. Antimicrob. Agents Chemother. 2000, 44, 3310-3316. [CrossRef]

76. Sahasrabudhe, K.S.; Kimball, J.R.; Morton, T.H.; Weinberg, A.; Dale, B.A. Expression of the antimicrobial peptide, human beta-defensin 1, in duct cells of minor salivary glands and detection in saliva. J. Dent. Res. 2000, 79, 1669-1674. [CrossRef]

77. Nadig, S.D.; Ashwathappa, D.T.; Manjunath, M.; Krishna, S.; Annaji, A.G.; Shivaprakash, P.K. A relationship between salivary flow rates and Candida counts in patients with xerostomia. J. Oral Maxillofac. Pathol. 2017, 21, 316. [CrossRef]

78. Karbach, J.; Walter, C.; Al-Nawas, B. Evaluation of saliva flow rates, Candida colonization and susceptibility of Candida strains after head and neck radiation. Clin. Oral Investig. 2012, 16, 1305-1312. [CrossRef]

79. Ohga, N.; Yamazaki, Y.; Sato, J.; Asaka, T.; Morimoto, M.; Hata, H.; Satoh, C.; Kitagawa, Y. Elimination of oral candidiasis may increase stimulated whole salivary flow rate. Arch. Oral Biol. 2016, 71, 129-133. [CrossRef]

80. Porcheri, C.; Mitsiadis, T.A. Physiology, pathology and regeneration of salivary glands. Cells 2019, 8, 976. [CrossRef]

81. Deshmukh, U.S.; Nandula, S.R.; Thimmalapura, P.-R.; Scindia, Y.M.; Bagavant, H. Activation of innate immune responses through Toll-like receptor 3 causes a rapid loss of salivary gland function. J. Oral Pathol. Med. 2009, 38, 42-47. [CrossRef]

82. Ferretti, S.; Bonneau, O.; Dubois, G.R.; Jones, C.E.; Trifilieff, A. IL-17, produced by lymphocytes and neutrophils, is necessary for lipopolysaccharide-induced airway neutrophilia: IL-15 as a possible trigger. J. Immunol. 2003, 170, 2106-2112. [CrossRef]

83. Kany, S.; Vollrath, J.T.; Relja, B. Cytokines in inflammatory disease. Int. J. Mol. Sci. 2019, 20, 6008. [CrossRef]

84. Festa, A.; D'Agostino, R.; Howard, G.; Mykkänen, L.; Tracy, R.P.; Haffner, S.M. Chronic subclinical inflammation as part of the insulin resistance syndrome: The Insulin Resistance Atherosclerosis Study (IRAS). Circulation 2000, 102, 42-47. [CrossRef]

85. Ohyama, Y.; Carroll, V.A.; Deshmukh, U.; Gaskin, F.; Brown, M.G.; Fu, S.M. Severe focal sialadenitis and dacryoadenitis in NZM2328 mice induced by MCMV: A novel model for human Sjögren's syndrome. J. Immunol. 2006, 177, 7391-7397. [CrossRef] [PubMed]

86. King, L.S.; Yasui, M. Aquaporins and disease: Lessons from mice to humans. Trends Endocrinol. Metab. 2002, 13, 355-360. [CrossRef] 
87. Yamamura, Y.; Motegi, K.; Kani, K.; Takano, H.; Momota, Y.; Aota, K.; Yamanoi, T.; Azuma, M. TNF- $\alpha$ inhibits aquaporin 5 expression in human salivary gland acinar cells via suppression of histone H4 acetylation. J. Cell Mol. Med. 2012, 16, $1766-1775$. [CrossRef] [PubMed]

88. Williams, D.W.; Lewis, M.A.O. Oral Microbiology: Isolation and identification of candida from the oral cavity. Oral Dis. 2008, 6, 3-11. [CrossRef]

89. Hellstein, J.W.; Marek, C.L. Candidiasis: Red and white manifestations in the oral cavity. Head Neck Pathol. 2019, 13, 25-32. [CrossRef]

90. Williams, D.; Lewis, M. Pathogenesis and treatment of oral candidosis. J. Oral Microbiol. 2011, 3, 3. [CrossRef]

91. Reamy, B.V.; Derby, R.; Bunt, C.W. Common tongue conditions in primary care. Am. Fam. Physician 2010, 81, 627-634.

92. Khan, T.S.; Muddebihal, F.; Koshy, A. Chronic atrophic candidiasis: A case report and review of literature. Univ. Res. J. Dent. 2015, 5, 123. [CrossRef]

93. Aoun, G.; Berberi, A. Prevalence of Chronic Erythematous Candidiasis in Lebanese Denture Wearers: A Clinico-microbiological Study. Mater. Sociomed. 2017, 29, 26-29. [CrossRef]

94. Sitheeque, M.A.M.; Samaranayake, L.P. Chronic hyperplastic candidosis/candidiasis (candidal leukoplakia). Crit. Rev. Oral Biol. Med. 2003, 14, 253-267. [CrossRef]

95. Sharon, V.; Fazel, N. Oral candidiasis and angular cheilitis. Dermatol. Ther. 2010, 23, 230-242. [CrossRef] [PubMed]

96. Zhou, P.R.; Hua, H.; Liu, X.S. Quantity of candida colonies in saliva: A diagnostic evaluation for oral candidiasis. Chin. J. Dent. Res. 2017, 20, 27-32. [PubMed]

97. Coronado-Castellote, L.; Jiménez-Soriano, Y. Clinical and microbiological diagnosis of oral candidiasis. J. Clin. Exp. Dent. 2013, 5, e279-e286. [CrossRef] [PubMed]

98. Garcia-Cuesta, C.; Sarrion-Pérez, M.-G.; Bagán, J.V. Current treatment of oral candidiasis: A literature review. J. Clin. Exp. Dent. 2014, 6, e576-e582. [CrossRef]

99. Vigneswaran, N.; Muller, S. Pharmacologic management of oral mucosal inflammatory and ulcerative diseases. In Contemporary Dental Pharmacology: Evidence-Based Considerations; Jeske, A.H., Ed.; Springer International Publishing: Cham, Switzerland, 2019; pp. 91-108.

100. Aguirre Urizar, J.M. Oral candidiasis. Rev. Iberoam Micol. 2002, 19, 17-21.

101. Martínez-Beneyto, Y.; López-Jornet, P.; Velandrino-Nicolás, A.; Jornet-García, V. Use of antifungal agents for oral candidiasis: Results of a national survey. Int. J. Dent. Hyg. 2010, 8, 47-52. [CrossRef]

102. Odds, F.C.; Brown, A.J.P.; Gow, N.A.R. Antifungal agents: Mechanisms of action. Trends Microbiol. 2003, 11, 272-279. [CrossRef]

103. Lombardi, A.; Ouanounou, A. Fungal infections in dentistry: Clinical presentations, diagnosis, and treatment alternatives. Oral Surg. Oral Med. Oral Pathol. Oral Radiol. 2020, 130, 533-546. [CrossRef]

104. Parente-Rocha, J.A.; Bailão, A.M.; Amaral, A.C.; Taborda, C.P.; Paccez, J.D.; Borges, C.L.; Pereira, M. Antifungal Resistance, Metabolic Routes as Drug Targets, and New Antifungal Agents: An Overview about Endemic Dimorphic Fungi. Mediators Inflamm. 2017, 2017, 9870679. [CrossRef]

105. Cowen, L.E.; Sanglard, D.; Howard, S.J.; Rogers, P.D.; Perlin, D.S. Mechanisms of Antifungal Drug Resistance. Cold Spring Harb. Perspect. Med. 2014, 5, a019752. [CrossRef]

106. Whaley, S.G.; Berkow, E.L.; Rybak, J.M.; Nishimoto, A.T.; Barker, K.S.; Rogers, P.D. Azole Antifungal Resistance in Candida albicans and Emerging Non-albicans Candida Species. Front. Microbiol. 2016, 7, 2173. [CrossRef] [PubMed]

107. Chang, Y.-L.; Yu, S.-J.; Heitman, J.; Wellington, M.; Chen, Y.-L. New facets of antifungal therapy. Virulence 2017, 8, 222-236. [CrossRef] [PubMed]

108. Pianalto, K.; Alspaugh, J. New horizons in antifungal therapy. J. Fungi 2016, 2, 26. [CrossRef] [PubMed]

109. Ghannoum, M.A.; Rice, L.B. Antifungal agents: Mode of action, mechanisms of resistance, and correlation of these mechanisms with bacterial resistance. Clin. Microbiol. Rev. 1999, 12, 501-517. [CrossRef]

110. Kumamoto, C.A. Candida biofilms. Curr. Opin. Microbiol. 2002, 5, 608-611. [CrossRef]

111. Vissink, A.; Mitchell, J.B.; Baum, B.J.; Limesand, K.H.; Jensen, S.B.; Fox, P.C.; Elting, L.S.; Langendijk, J.A.; Coppes, R.P.; Reyland, M.E. Clinical management of salivary gland hypofunction and xerostomia in head-and-neck cancer patients: Successes and barriers. Int. J. Radiat. Oncol. Biol. Phys. 2010, 78, 983-991. [CrossRef]

112. Silvestre, F.J.; Minguez, M.P.; Suñe-Negre, J.M. Clinical evaluation of a new artificial saliva in spray form for patients with dry mouth. Med. Oral Patol. Oral Cir. Bucal 2009, 14, E8-E11.

113. Jansma, J.; Vissink, A.; Spijkervet, F.K.; Roodenburg, J.L.; Panders, A.K.; Vermey, A.; Szabó, B.G.; Gravenmade, E.J. Protocol for the prevention and treatment of oral sequelae resulting from head and neck radiation therapy. Cancer 1992, 70, $2171-2180$. [CrossRef]

114. Jellema, A.P.; Slotman, B.J.; Doornaert, P.; Leemans, C.R.; Langendijk, J.A. Impact of radiation-induced xerostomia on quality of life after primary radiotherapy among patients with head and neck cancer. Int. J. Radiat. Oncol. Biol. Phys. 2007, 69, 751-760. [CrossRef]

115. Gibson, J.; Halliday, J.A.; Ewert, K.; Robertson, S. A controlled release pilocarpine buccal insert in the treatment of Sjögren's syndrome. Br. Dent. J. 2007, 202, E17. [CrossRef]

116. Tabata, Y. Tissue regeneration based on growth factor release. Tissue Eng. 2003, 9 (Suppl. S1), S5-S15. [CrossRef] 
117. Richards Grayson, A.C.; Choi, I.S.; Tyler, B.M.; Wang, P.P.; Brem, H.; Cima, M.J.; Langer, R. Multi-pulse drug delivery from a resorbable polymeric microchip device. Nat. Mater. 2003, 2, 767-772. [CrossRef] [PubMed]

118. Hirsch, L.R.; Gobin, A.M.; Lowery, A.R.; Tam, F.; Drezek, R.A.; Halas, N.J.; West, J.L. Metal nanoshells. Ann. Biomed. Eng. 2006, 34, 15-22. [CrossRef] [PubMed]

119. Sershen, S.R.; Mensing, G.A.; Ng, M.; Halas, N.J.; Beebe, D.J.; West, J.L. Independent Optical Control of Microfluidic Valves Formed from Optomechanically Responsive Nanocomposite Hydrogels. Adv. Mater. Weinheim 2005, 17, 1366-1368. [CrossRef]

120. Delporte, C.; O'Connell, B.C.; He, X.; Lancaster, H.E.; O'Connell, A.C.; Agre, P.; Baum, B.J. Increased fluid secretion after adenoviral-mediated transfer of the aquaporin-1 cDNA to irradiated rat salivary glands. Proc. Natl. Acad. Sci. USA 1997, 94, 3268-3273. [CrossRef] [PubMed]

121. Alevizos, I.; Zheng, C.; Cotrim, A.P.; Liu, S.; McCullagh, L.; Billings, M.E.; Goldsmith, C.M.; Tandon, M.; Helmerhorst, E.J.; Catalán, M.A.; et al. Late responses to adenoviral-mediated transfer of the aquaporin-1 gene for radiation-induced salivary hypofunction. Gene Ther. 2017, 24, 176-186. [CrossRef]

122. Samuni, Y.; Baum, B.J. Gene delivery in salivary glands: From the bench to the clinic. Biochim. Biophys. Acta 2011, 1812, $1515-1521$. [CrossRef]

123. Varghese, J.J.; Schmale, I.L.; Wang, Y.; Hansen, M.E.; Newlands, S.D.; Ovitt, C.E.; Benoit, D.S.W. Retroductal nanoparticle injection to the murine submandibular gland. J. Vis. Exp. 2018, 135, e57521. [CrossRef]

124. Shan, Z.; Li, J.; Zheng, C.; Liu, X.; Fan, Z.; Zhang, C.; Goldsmith, C.M.; Wellner, R.B.; Baum, B.J.; Wang, S. Increased fluid secretion after adenoviral-mediated transfer of the human aquaporin-1 cDNA to irradiated miniature pig parotid glands. Mol. Ther. 2005, 11, 444-451. [CrossRef]

125. Redman, R.S.; Ball, W.D.; Mezey, E.; Key, S. Dispersed donor salivary gland cells are widely distributed in the recipient gland when infused up the ductal tree. Biotech. Histochem. 2009, 84, 253-260. [CrossRef]

126. Grundmann, O.; Fillinger, J.L.; Victory, K.R.; Burd, R.; Limesand, K.H. Restoration of radiation therapy-induced salivary gland dysfunction in mice by post therapy IGF-1 administration. BMC Cancer 2010, 10, 417. [CrossRef] [PubMed]

127. Okazaki, Y.; Kagami, H.; Hattori, T.; Hishida, S.; Shigetomi, T.; Ueda, M. Acceleration of rat salivary gland tissue repair by basic fibroblast growth factor. Arch. Oral Biol. 2000, 45, 911-919. [CrossRef]

128. Zheng, C.; Cotrim, A.P.; Rowzee, A.; Swaim, W.; Sowers, A.; Mitchell, J.B.; Baum, B.J. Prevention of radiation-induced salivary hypofunction following hKGF gene delivery to murine submandibular glands. Clin. Cancer Res. 2011, 17, 2842-2851. [CrossRef] [PubMed]

129. Marmary, Y.; Adar, R.; Gaska, S.; Wygoda, A.; Maly, A.; Cohen, J.; Eliashar, R.; Mizrachi, L.; Orfaig-Geva, C.; Baum, B.J.; et al. Radiation-Induced Loss of Salivary Gland Function Is Driven by Cellular Senescence and Prevented by IL6 Modulation. Cancer Res. 2016, 76, 1170-1180. [CrossRef]

130. Lombaert, I.M.A.; Wierenga, P.K.; Kok, T.; Kampinga, H.H.; de Haan, G.; Coppes, R.P. Mobilization of bone marrow stem cells by granulocyte colony-stimulating factor ameliorates radiation-induced damage to salivary glands. Clin. Cancer Res. 2006, 12, 1804-1812. [CrossRef] [PubMed]

131. Lombaert, I.M.A.; Brunsting, J.F.; Wierenga, P.K.; Kampinga, H.H.; de Haan, G.; Coppes, R.P. Cytokine treatment improves parenchymal and vascular damage of salivary glands after irradiation. Clin. Cancer Res. 2008, 14, 7741-7750. [CrossRef]

132. Rocchi, C.; Emmerson, E. Mouth-Watering Results: Clinical Need, Current Approaches, and Future Directions for Salivary Gland Regeneration. Trends Mol. Med. 2020, 26, 649-669. [CrossRef]

133. Jensen, D.H.; Oliveri, R.S.; Trojahn Kølle, S.-F.; Fischer-Nielsen, A.; Specht, L.; Bardow, A.; Buchwald, C. Mesenchymal stem cell therapy for salivary gland dysfunction and xerostomia: A systematic review of preclinical studies. Oral Surg. Oral Med. Oral Pathol. Oral Radiol. 2014, 117, 335-342.e1. [CrossRef]

134. Lim, J.-Y.; Yi, T.; Choi, J.-S.; Jang, Y.H.; Lee, S.; Kim, H.J.; Song, S.U.; Kim, Y.-M. Intraglandular transplantation of bone marrowderived clonal mesenchymal stem cells for amelioration of post-irradiation salivary gland damage. Oral Oncol. 2013, 49, 136-143. [CrossRef] [PubMed]

135. Kojima, T.; Kanemaru, S.-I.; Hirano, S.; Tateya, I.; Ohno, S.; Nakamura, T.; Ito, J. Regeneration of radiation damaged salivary glands with adipose-derived stromal cells. Laryngoscope 2011, 121, 1864-1869. [CrossRef] [PubMed]

136. Grønhøj, C.; Jensen, D.H.; Glovinski, P.V.; Jensen, S.B.; Bardow, A.; Oliveri, R.S.; Specht, L.; Thomsen, C.; Darkner, S.; Kiss, K.; et al. First-in-man mesenchymal stem cells for radiation-induced xerostomia (MESRIX): Study protocol for a randomized controlled trial. Trials 2017, 18, 108. [CrossRef] [PubMed]

137. Grønhøj, C.; Jensen, D.H.; Vester-Glowinski, P.; Jensen, S.B.; Bardow, A.; Oliveri, R.S.; Fog, L.M.; Specht, L.; Thomsen, C.; Darkner, S.; et al. Safety and Efficacy of Mesenchymal Stem Cells for Radiation-Induced Xerostomia: A Randomized, Placebo-Controlled Phase 1/2 Trial (MESRIX). Int. J. Radiat. Oncol. Biol. Phys. 2018, 101, 581-592. [CrossRef] [PubMed]

138. Barkholt, L.; Flory, E.; Jekerle, V.; Lucas-Samuel, S.; Ahnert, P.; Bisset, L.; Büscher, D.; Fibbe, W.; Foussat, A.; Kwa, M.; et al. Risk of tumorigenicity in mesenchymal stromal cell-based therapies-bridging scientific observations and regulatory viewpoints. Cytotherapy 2013, 15, 753-759. [CrossRef]

139. Van Luijk, P.; Pringle, S.; Deasy, J.O.; Moiseenko, V.V.; Faber, H.; Hovan, A.; Baanstra, M.; van der Laan, H.P.; Kierkels, R.G.J.; van der Schaaf, A.; et al. Sparing the region of the salivary gland containing stem cells preserves saliva production after radiotherapy for head and neck cancer. Sci. Transl. Med. 2015, 7, 305ra147. [CrossRef] 
140. Pringle, S.; Maimets, M.; van der Zwaag, M.; Stokman, M.A.; van Gosliga, D.; Zwart, E.; Witjes, M.J.H.; de Haan, G.; van Os, R.; Coppes, R.P. Human salivary gland stem cells functionally restore radiation damaged salivary glands. Stem Cells 2016, 34, 640-652. [CrossRef]

141. Ihrler, S.; Blasenbreu-Vogt, S.; Sendelhofert, A.; Rössle, M.; Harrison, J.D.; Löhrs, U. Regeneration in chronic sialadenitis: An analysis of proliferation and apoptosis based on double immunohistochemical labelling. Virchows Arch. 2004, 444, 356-361. [CrossRef]

142. Aure, M.H.; Konieczny, S.F.; Ovitt, C.E. Salivary gland homeostasis is maintained through acinar cell self-duplication. Dev. Cell 2015, 33, 231-237. [CrossRef]

143. Boshell, J.L.; Pennington, C. Histological observations on the effects of isoproterenol on regenerating submandibular glands of the rat. Cell Tissue Res. 1980, 213, 411-416. [CrossRef]

144. Maimets, M.; Bron, R.; de Haan, G.; van Os, R.; Coppes, R.P. Similar ex vivo expansion and post-irradiation regenerative potential of juvenile and aged salivary gland stem cells. Radiother. Oncol. 2015, 116, 443-448. [CrossRef]

145. Feng, J.; van der Zwaag, M.; Stokman, M.A.; van Os, R.; Coppes, R.P. Isolation and characterization of human salivary gland cells for stem cell transplantation to reduce radiation-induced hyposalivation. Radiother. Oncol. 2009, 92, 466-471. [CrossRef]

146. Patel, V.N.; Lombaert, I.M.A.; Cowherd, S.N.; Shworak, N.W.; Xu, Y.; Liu, J.; Hoffman, M.P. Hs3st3-modified heparan sulfate controls KIT+ progenitor expansion by regulating 3-O-sulfotransferases. Dev. Cell 2014, 29, 662-673. [CrossRef] [PubMed]

147. Banh, A.; Xiao, N.; Cao, H.; Chen, C.-H.; Kuo, P.; Krakow, T.; Bavan, B.; Khong, B.; Yao, M.; Ha, C.; et al. A novel aldehyde dehydrogenase-3 activator leads to adult salivary stem cell enrichment in vivo. Clin. Cancer Res. 2011, 17, 7265-7272. [CrossRef] [PubMed]

148. Nakao, K.; Morita, R.; Saji, Y.; Ishida, K.; Tomita, Y.; Ogawa, M.; Saitoh, M.; Tomooka, Y.; Tsuji, T. The development of a bioengineered organ germ method. Nat. Methods 2007, 4, 227-230. [CrossRef] [PubMed]

149. Ogawa, M.; Oshima, M.; Imamura, A.; Sekine, Y.; Ishida, K.; Yamashita, K.; Nakajima, K.; Hirayama, M.; Tachikawa, T.; Tsuji, T. Functional salivary gland regeneration by transplantation of a bioengineered organ germ. Nat. Commun. 2013, 4, 2498. [CrossRef]

150. Hirayama, M.; Oshima, M.; Tsuji, T. Development and prospects of organ replacement regenerative therapy. Cornea 2013, 32 (Suppl. S1), S13-S21. [CrossRef] 